\title{
TWO DECADES FIGHTING INHUMAN NATURES: NAOMI WALLACE'S IN THE HEART OF AMERICA (1994)
}

\author{
Rovie HERRERA MEDALle \\ Universidad de Málaga \\ rovie@uma.es
}

Received 17 October 2017

Accepted 23 April 2018

\section{KEYWORDS}

Naomi Wallace; In the Heart of America; Gulf War; contemporary drama; cognitive approach; spectatorship; queer studies.

\section{PALABRAS CLAVE}

Naomi Wallace; In the Heart of America; Guerra del Golfo; teatro contemporáneo; aproximación cognitiva; análisis del espectador; estudios queer.

\begin{abstract}
Naomi Wallace is one of the most representative voices of contemporary American women's drama. Wallace's plays have been produced for over twenty years in the USA and around the world. The dramatist presents a political writing that rattles the theaters with experimental techniques, unfamiliar characters, and intricate stories. Although many of Wallace's recent plays have been well received by the audience, In the Heart of America (1994) is still praised as her masterpiece. This essay discusses the aspects that make In the Heart of America, after two decades of production, her bestknown and most recognized play. Focused on the spectatorial experience, this essay provides insights into cognitive theories by Giovanna Colombetti and Bruce McConachie applied to spectatorship that cast some light on Wallace's complex drama.
\end{abstract}

\section{RESUMEN}

Naomi Wallace es una de las voces femeninas más representativas del teatro estadounidense contemporáneo. Durante más de veinte años sus obras han sido representadas en Estados Unidos y alrededor del mundo. El estilo político de su escritura impacta en el teatro a través de sus técnicas más experimentales y sus personajes e historias complejas. A pesar de que muchas de sus obras más recientes han sido aclamadas por el público, In the Heart of America (1994) sigue siendo considerada como su gran obra maestra. El presente ensayo aborda los aspectos que hacen que In the Heart of America tras más de dos décadas de representaciones sea a día de hoy su 
obra más reconocida. Centrado en la experiencia del espectador, este ensayo tratará de desvelar la complexidad de su obra mediante el uso de teorias cognitivas propuestas por Giovanna Colombetti y Bruce McConachie.

In November 1994 in New Haven, Connecticut, Tony Kushner directed In the Heart of America by Naomi Wallace at the Long Wharf Theater. More than twenty years have passed since this first production and it could be said that in the last two decades Wallace has built a successful career as a dramatist. She is a McArthur Genius recipient and has written many other acclaimed plays, such as The Liquid Plain (2012), which was premiered at the Oregon Shakespearean Festival and awarded with the Horton Foote Prize in 2012. Interestingly, notwithstanding the recognition of her plays after the millennium-such as And I and Silence (2010) or Night is a Room (2015) - In the Heart of America (1994) is still regarded as her masterpiece because, as I will argue, it arouses the least emotional spectatorial response.

Dealing with one of her most recurrent topics, war, Wallace explores in/human nature in In the Heart of America. Political, empowering, and interconnected with the advent of queer studies in the 90s, In the Heart of America stands as a significant work in the oeuvre of a generation of women playwrights-such as Susan LoriParks, Carson Kreitzer, and Sarah Ruhl among many others-who took to the American stage to innovate and present new theatrical forms. Therefore, the purpose of this essay is to analyze how in In the Heart of America Naomi Wallace successfully portrays the Gulf War in a thought-provoking and avant-garde style, opening a conversation about war, love, and prejudice, in order to call the spectator's attention to the injustice of preconceived notions of identity and sexuality. I believe that my theoretical approach, based on the cognitive turn and performance studies by Giovanna Colombetti and Bruce McConachie, helps to cast some light on this complex theatrical work.

A motel room serves as the starting point where Fairouz Saboura and Craver Perry meet in In the Heart of America; Craver, a young soldier "white male, early twenties" (80) who served in the Gulf War, reluctantly answers the questions of Fairouz, "a PalestinianAmerican, mid-twenties" (80). She is looking for her brother, Remzi Saboura, who disappeared while he was serving with Craver. Wallace unravels Remzi's story through a political journey that intertwines with her personal and provocative vision of the Gulf War. The 
playwright also includes echoes of the Vietnam War introduced by two ghosts, namely Lue Ming, a victim of the war, and Boxler, a vicious, sadistic Lieutenant. These ghosts from the past interact with the characters in the present challenging their views on the ongoing war. It is difficult to classify the play, as belonging to a particular genre, since Wallace deals with a wide range of topics such as war, love, and politics with different voices and the tones vary from tragic, to comic, critical, sentimental or even raw. In the Heart of America can be well defined as experimental, contemporary, and socially committed, although the playwright herself defines it as "just a love story" (Bayley).

One of the prominent aspects that made In the Heart of America one of her most well-known plays is related to the real facts that Wallace tackles in her story. The staging of inhuman atrocities of war that she deals with present a conflict in creative terms since, as Wallace ponders, "How do you creatively say, '5,000 children are dying a month'?" (Margulies and Wallace 36). The dramatist solves this conflict by giving some space to the story for the narration to breathe between scenes. In In the Heart of America, Wallace does not place the issue of war upfront; instead, she interweaves the present with the war scenes, which she locates in a distant past. The setting in the past also avoids the battlefield and presents a military camp during the Gulf War where two young soldiers, Remzi and Craver, meet for the first time. This disruption of the timeline in the play testifies to the influence of Brechtian theater in Wallace's dramaturgy; the playwright herself recognizes that sometimes during the creative process she attempts to attain distance in Brechtian fashion: "My approach is to step back far enough so that I can see more clearly. Similar perhaps to what Brecht calls 'making strange" (MacDonald 97). Furthermore, I believe that Wallace's drama, as well as that of other contemporary women playwrights, has already transcended the shadow of Brechtian theater to allow her to make a kind of theater where she raises her own voice and presents her own conflicts as an artist. One can well borrow Elin Diamond's analysis of neo-Brechtian women playwrights and their use of historicization, since it is still an interesting approach for the analysis of Wallace's drama. As Diamond explains:

The understanding of women's material conditions in history, and the problematics of uncovering 'women's history' are topoi in feminist theory that Brecht's theory of historicization greatly 
informs. Brecht understood social relations, particularly class relations, as part of a moving dialectic [...] There is a powerful dialectical movement in Brechtian historicization of preserving the 'distinguishing marks' of the past and acknowledging, even foregrounding, the audience's present perspective. (Diamond 45)

There is a remarkable array of Wallace's works in which dialectics functions as a pivotal instrument, plays such as One Flea Spare (1995) or And I and Silence (2010) are structured around dialectics where race, class, and gender relations provide the argument to move the plot; she sets the tensions between servants and masters in both plays but also between races, as happens with the white and the African-American protagonists of And I and Silence. In the Heart of America provides a particular case study in dialectical terms, since, in addition to the racial hostility present in the play, the dramatist introduces a dialectical dialogue between two concepts which are much more abstract: the dynamics between war and love. Dialectics, as Diamond implies in the quotation above, serves as the vehicle of historicization, which is undoubtedly a core element in Wallace's play, in as much as she appropriates historical facts and tells her/history from an unfamiliar perspective, not paying special attention to the belligerent conflict but taking a close look at the characters' circumstances in this particular hostile zone. The fact that she plays with time has much to do with historicization and the collision between the past and the present. Commenting on the disrupted timeline of In the Heart of America in an interview, Wallace states:

I think [it is] because of my strong belief that wherever there is a present moment, the past is also present, although it's usually invisible. That's what draws me to theatre--the ability to put different times on stage and see how they collide or how they resonate with one another--how the past tells a story within a present story. (Istel 26)

The stage directions of In the Heart of America concerning the timeline are as follows: "All scenes are in the present time of the story, except for the scenes between Remzi and Craver, and Remzi and Fairouz, which take place in the past. In some scenes the past and present collide" (Wallace, In the Heart 80). In regard to the setting, the present in the play takes place in the motel room, where Fairouz questions Craver. As Wallace explains, the past-which is 
invisible for Fairouz but very visible for the spectators through flashbacks-reveals the coarse reality of these two soldiers at the front. As seen in the quotation above, for Wallace, the past in a certain manner interferes with the present. Moreover, the echoes from the past that resonate in the present are reinforced by two spectral characters from the Vietnam War that complete the cast and contribute to make an unusual-perhaps strange, in a neo-Brechtian use of epic theater-portrait of war: Lue Ming, a Vietnamese woman, is described as "a ghost, but more solid" (80) and Boxler as "the soul of Lieutenant Calley" (80). ${ }^{1}$ Both characters have a bodily reality and they are antagonistic figures, that is, the pacifist woman versus the aggressive male. In those scenes where past and present collide, Wallace establishes a parallelism between the Vietnam War and the Gulf War with the purpose of raising the spectators' awareness. Hence, if the Vietnam War was more objectively recognized as unnecessary and a failure with the passing of time for many Americans, the fact of taking back the Gulf War and placing it on stage three years after it ended also opens the possibility of contemplating it with perspective, as well as suggesting that it has been also a failure. As stated before, Brechtian historicization has much to do with this parallelism between wars from different times; Wallace plays not only with time but also with historical events to express her own artistic vision about the sociopolitical conflicts. However, it should be acknowledged that she thoroughly researches the topics she presents on stage; some of her plays have been published with a bibliography to invite readers to inform themselves on the subject matter.

Apart from raising the spectators' awareness concerning the barbarity of war and its political appeal, In the Heart of America is above all a love story between the two soldiers. This love story brings about the inner conflicts of the soldiers who at their young age cope with a reality which engages the spectator in a play that goes beyond politics to deal with social and personal issues. The protagonists face a dreadful situation and they are forced to fight unexpected battles

\footnotetext{
${ }^{1}$ Lieutenant Calley was convicted over the killings at My Lai where around 400 unarmed civilians were killed indiscriminately. He was sentenced to life in prison, later reduced to 20 years and house arrest. For more information, see http://www.telegraph.co.uk/news/worldnews/6072064/My-Lai-massacre-Lt-WilliamCalley- apologises-more-than-40-years-after-Vietnam.html
} 
against prejudice, racism, and homophobia. Remzi is a PalestinianAmerican and Craver, towards the end of the play, identifies himself as "a White Trash, River Boy, Arab-kissing Faggot" (114). The spectator is invited to see the progression of the characters during the play coming to terms with their sexuality; the young men are in a quest for their own identity, as well as their role in the Vietnam War. The case of Remzi is particularly complex since it is not only related to sexuality, as in the case of Craver, but also to race; he is an American citizen fighting against his country's enemy and by resorting to joining the army he dishonors his Palestinian ancestry. This is well illustrated in a flashback to the past where Fairouz states:

FAIROUZ: Go say good-bye to Mother. She's in her room, and she won't come out. She says they'll kill you. Just like they killed Father [...] I've told Mother that, Remzi. Over and over I've told her that it's the Iraqis you're going off to fight, but she keeps saying (Speaks in Arabic and then translates) "They'll kill him. The Yankees will kill him." Silly old woman. She's all mixed up. (103-4)

Remzi's family feels alienated in the midst of American society and its culture, which is much related with the fact that the Americans killed his father in what appears to be a hate crime. Although the women in the family struggle with this racial and cultural conflict, they embrace their inheritance. Fairouz is particularly conscious of her ancestry, which causes a disagreement between her and Remzi. As they argue:

FAIROUZ: I'm an Arab woman.

REMZI: You've never even been there.

FAIROUZ: Neither have you!

REMZI: If you walked into our village today, they'd tar and feather you.

FAIROUZ: Fuck you, I'd put on a veil.

REMZI: The veil's not the problem. You haven't been a virgin since you were thirteen.

FAIROUZ: How dare you! (93-4)

Differing from his sister's position, Remzi struggles to find his niche and to define his identity as an American citizen. On this account, he joins the army to prove himself valuable to his country and regain 
the sense of belonging, he explains: "I'm sick of being a hyphen: the Palestinian, the gap between Arab-American. There's room for me here. Where I have my friends" (95). However, Remzi's experience at the battlefront, rather than grant him a purpose in life, confuses him even more, since he has to come to terms with the futility of war. In this schema, the spectator follows Remzi's journey as an active subject who is well invested in the action; Wallace discloses progressively Remzi's story inviting the spectator to feel sympathy and acknowledge his fortitude.

The play poses the question of how determinist forces conspire against the subjects' will. An example of this in the play is the prejudice at the battlefront, which is concealed thanks to other highlighted elements of war such as patriotism or fighting for justice and principles. Wallace denounces how immigrants or descendants of immigrants are dying on behalf of a country that does not accept them as equals, as well as how the undercurrent homophobia within the US army was particularly latent in the 90s. She stresses society's proclivity to label and to point at differences, which causes a natural postmodern quest of identity. Characters such as Remzi or Greg in her all male cast in the play The War Boys (1993) represent the contradiction of being American citizens identified as alien subjects as a consequence of their ancestry. Both plays, In the Heart of America and The War Boys, criticize the objectification of subjects within society and the dehumanization of its individuals by turning them into profit for the capitalistic system. Accordingly, the character of Remzi, once he acknowledges his role at the battlefront, questions the reasons for fighting in Iraq, and he states:

REMZI: Why are we here (Beat) killing Arabs?

CRAVER: For love? Say it's for love. Don't say for oil. Don't say for freedom. Don't say for world power. I'm sick of that. I'm so fucking sick of that. It's true, isn't it? We're here for love. Say it just once. For me.

REMZI: We're here for love.

(They kiss) (124)

Ironically, the characters find love in one of the most sadistic contexts possible, a war zone. The contrast between love and war or loving and killing is emphasized not only by the landscape but also by the rhetoric, since Wallace was interested in how the same human body is capable of both killing and loving. This dichotomy is the 
vehicle for the spectator to experience a range of emotions that go from the most human to the most inhuman. As Craver explains:

CRAVER: Because I fell in love. In our bunkers at night, Remzi used to read the names out loud to us, and it calmed us down. He must have read that weapons manual a hundred times. All those ways to kill the human body. Lullabies. It was like ... they were always the same and always there, and when we said them to ourselves there was nothing else like it: Fishbeds, Floggers and Fulcrums. Stringers, Frogs, Silkworms, Vulcans, Beehives and Bouncing Bettys. (111)

The audience follows the performers through this journey, which is woven through with some aspects of military rhetoric with sexual innuendos. Referring to The Retreating World (2008), which was also set during the Gulf War, Wallace explains that the military rhetoric plays an important part in her play. She asserts, "the character talks about the intimate details of his life and the people he knew. His struggle with those pieces of rhetoric-the list of weapons and the numbers of bombs-represent my own struggle as a playwright" (Margulies and Wallace 36). The sexual repression of both Remzi and Craver is at first released through their sensual dialogues about the weapons of destruction- "Have you ever run your face over a wing of an A-6 Intruder, or opened your mouth into the tail of a AV-8B Harrier II?" (113)-Wallace also plays with the significance of the names of the bombs, such as "Sad Eyes" (87). Sex is presented as the vehicle for healing the wounded body but also the soul in pain.

According to Scott T. Cummings, most characters in Wallace's plays have a wound; as he observes, "A character defined by social or demographic type is often individuated by a singular history that includes illness, injury, or some form of physical violation that has resulted in permanent scars, a wound that will not heal, or other lasting effects" (37). Analyzing Wallace's plays one comes across several characters wounded in very different ways; this is particularly evident in Slaughter City (1996), where she stresses the wounded body in labor exploitation, in which most of the characters have injuries. Cummings studies Wallace's characters in these terms and affirms:

They gravitate towards each other with sexual longing that is conditioned by a history of violence, complicated by social and political divisions, and in some instances gratified in startling and theatrical ways. Their wounds-and there are more of them in these 
and other plays - are the outward physical signs of a legacy of pain and a life of oppression. In Wallace, the body is poked, prodded, pierced, penetrated, and pulverized, revealing a vulnerability that is reinforced by gruesome imagery and a general air of carnage. (38)

As a socialist writer, Wallace emphasizes the struggle of the proletariat and how the capitalistic system profits through exploitation of workers - which in the case of In the Heart of America is portrayed by lower rank soldiers-that strive for survival as underdogs. Notwithstanding this, it is worth mentioning that Wallace's drama stands as an evolved form of Artaudian and Brechtian theater, which exceeds the agitprop by providing a more complex canvas for her stories.

Although Wallace deals with universal topics such as war, love, and sex, the fact that In the Heart of America was first acclaimed in the United Kingdom and some of her plays also became popular in France is worthy of comment: as a consequence of her rebellious and radical style, she initially had a better acceptance in Europe. Thus, nowadays she combines her residency between England and the United States. As Barbara Ozieblo points out, Wallace is "more frequently performed in England than in America where certainly her earlier plays have been considered too serious and ideologically committed" ("From Shirtwaist" 117). Although the play can be acknowledged as one of her most acclaimed pieces, In the Heart of America was also criticized in some reviews in the USA. For instance, in a review on the website CurtainUp.com (The Internet Theater Magazine of Reviews, Features, Annotated Listings) of the Philadelphia premier of In the Heart of America (1994) Kathryn Osenlund states: "Most of all In the Heart of America is disappointing because it lacks clarity, with nothing fully realized. The problem is not so much the murk of war or memory, but the murk of muddled writing" (Osenlund). This aspect is related to Wallace's statement: "entertainment should be challenging and dangerous" (Introduction" 426), since as the review above illustrates, not all spectators are willing to take up the challenge. Moreover, contemplating Antonin Artaud's Theatre and Its Double (1958) and his definition of Theater of Cruelty, one sees the relevance of danger in theater, which is similar to Wallace's definition of entertainment. Artaud states that "[t]he best way, it seems to me, to realize the idea of danger on the stage is by the objective unforeseen, the unforeseen not in situations but in things, the abrupt, untimely transition from an intellectual 
image to a true image" (44, author's emphasis). In order to illustrate this idea, Artaud uses the example of a man who is blaspheming and he "sees suddenly and realistically materialized before him the image of his blasphemy (always on condition, I would add, that such an image is not entirely gratuitous but engenders in its turn other images in the same spiritual vein, etc.)" (44). Likewise, Wallace uses this device in In the Heart of America, where Boxler faces his victim, Lue Ming, years after he had killed her. As Artaud points out, 'danger'-and I will also add 'challenge' borrowing Wallace's wordsis essential in theater. Both features serve to expedite an engagement of the spectator, which I recognize as Wallace's main aim as a playwright.

I believe that one of the key aspects that prompted the success of In the Heart of America is that Wallace offers an intense experience to the spectator, who undergoes different emotions throughout the play. Recent cognitive studies that deal with the performing arts demonstrate that in theatrical events the spectator undergoes what is defined as "emotional episodes," which are brief episodes much more complex than basic emotions. The nature of emotions has been analyzed as an inextricable relationship between the mind inside the body and this body which, at the same time, is in conversation with the environment, that is, with the circumstances that surround it. Some cognitive scientists, such as Giovanna Colombetti, believe that the nature of emotions is the cause "of evolutionary and developmental factors that shape the organism in a certain way" (Colombetti 70), which makes the emotional episodes flexible structures in dynamical emotion systems. Colombetti, as an affective scientist, properly refers to emotions as 'emotional episodes,' because she understands emotions as short-lived episodes, which are flexible and variable. As a result of this, affective scientists reject the conventional division of basic emotions. It is not a matter of the spectator simply feeling anger at Remzi's story, instead, the action on stage arouses a much more complex experience where she/he experiences anger, frustration, pity, and/or shame.

Therefore, to analyze the spectator's experience through basic emotions, which are understood as building-block categories would be very restrictive. Another characteristic of emotional episodes is that they are also sense-making systems as part of the evolutionary process. Hence, the performer gathers the feeling of the audience through their expressions as part of their emotions, consequently making sense and communicating at the same time. This part of the 
communicative process in theater is neglected in mediated events where the performers do not receive feedback from the audience. Concerning response, Colombetti centers her position on the redefinition of appraisal, since she believes that the bodily aspects of emotion have been dismissed as noncognitive aspects usually defined as responses, which are external to the process of appraising. She affirms, "in psychology, appraisal has typically been characterized as a factor or component of emotion neatly distinct from these bodily aspects [...] appraisal has been characterized as a disembodied cognitive phenomenon" (author's emphasis, 83). Interestingly, Colombetti pays attention to the body that performs, and defines it as the performative body; she explains:

The performative body is neither transparent nor an intentional object of awareness; it is the body as experienced during the skillful performance of a specific activity, when one need not attend to one's body but is nevertheless very much aware of its presence and activity. [...] The performative body is mainly constituted by prereflective proprioceptive and kinesthetic sensations, namely, sensations of bodily position and movement that are not attended. $(117-8)$

A very revealing aspect that Colombetti points out in her affective science and enactive mind theory is the localization of sensation of the body such as tingling in the stomach, throat contraction for disgust, and warm face as a consequence of embarrassment (118). Spectators experience these sensations in their bodies linked to the emotions appraised ${ }^{2}$ by the spectacle. Colombetti takes theater into consideration when she analyzes this feature using the arts as an example; she states:

In dance and theater, the same movement, such as a head lift, can have very different qualities, depending, for example, on the speed at which it is executed (paintings and sculptures can also evoke movement by representing, e.g., humans and animals, but also objects, in specific actions and by exploiting light and texture). Arguably, these portrayals can effectively evoke specific emotions because they reproduce bodily movements analogous to those we

\footnotetext{
2 Colombetti uses the term "appraisal" as part of the embodied emotions, which are not merely responses (84).
} 
often experience in our body when we feel the portrayed emotions. (119-20)

As Colombetti suggests, in theater gestures are meaningful-which support the assertions of many dramatists and performance theories-and evoke different emotions that lead the spectators to perceive the performers and evoke emotional episodes; this is especially notable in the case of comedy where sometimes a posture or even a facial expression can provoke laughter. With reference to facial expression and muscular activity, she addresses the muscular bonding phenomenon where subjects involved in social events, such as ritual, community, and different types of performance, experience coupling. This gives us a quite different perspective from the stimulus-response pattern. Emotional episodes in theater are part of a whole-governed by coordinative physical structures, neural structures, and interpersonal relations-in which the embodied mind/brain or mind/brain as part of the body are key to the spectator's experience.

The communal and social experience in theater has been also studied through the cognitive capability of empathy. Bruce McConachie has pointed out the differences between empathy and sympathy, usually misunderstood in audience reception. As I pointed out, Wallace's critical and intricate complex vision of historical events and American society has not always received flattering reviews. The fact that her characters are unusual and move in dreamlike scenarios presents some difficulties for the spectator to feel identified or aligned with the characters. Lindsay B. Cummings studies the relationship between empathy and performance in In the Heart of America in her essay "Naomi Wallace and the Dramaturgy of Rehersal" (Cummings and Abbitt, 71) suggesting a contextualization of Brecht's and Stanislavski's theories. I agree with Cummings that Brechtian theories should be revisited and contextualized, since it is in the scholars' best interest to study the aspects of empathy in order to understand performance but I do differ in how those theories should be understood. Empathy and sympathy are completely different concepts; some findings on cognition contradict the assumption that empathy can be controlled since it is inextricably related to our mirror neurons functions.

According to Vittorio Gallese's study and his discovery of mirror neurons, empathy operates in the unconscious. This 
breakthrough helped to understand not only how our brain works, but it also explains how we understand others' performances. As Vittorio Gallese, Christian Keysers, and Giacomo Rizzolatti explain: when a subject observes an individual performing an action "the observation of an action leads to the activation of parts of the same cortical neural network that is active during its execution. The observer understands the action because he knows its outcomes when he does it" (396). Action understanding depends on engagement, on the visual information of the spectator, and the understanding of the performer's movements and gestures. As Bruce McConachie points out:

When the heroes and villains of the performance can be personified, the action of picking a desired winner usually leads to two other major emotional investments [...] when spectators respond with anger, fear, and/or derisive laughter to the negative characters in dramas and dances. The antipathy that results from this cognitiveaffective process (and the sympathy inspired by positive actor/roleplayers) is a mode of psychological projection. That is, spectators project their own emotions, values, and desires onto blended players in a performance. (Evolution 100, author's bold type emphasis)

These blends that McConachie points out are part of the spectator's capability to understand the performance and to live the event as real and at the same time as fiction. Even though the spectator in Wallace's plays is usually unable to clearly distinguish between heroes and villains, In the Heart of America poses a different pattern since it would be inhuman to sympathize with a character like Boxler, who is portrayed as a cold-blooded soldier. Wallace has paired the male experience to violence in other plays such as The War Boys, as Helen Huff points out: "Wallace finds an appropriate male voice for these characters as she describes this male experience linking violence and sadism to sex, race, wealth and privilege" (55). Lue Ming, the Vietnamese civilian, confronts Boxler in a scene where she reveals for the audience that Boxler killed her daughter. Women in the play reinforce Wallace's critical view of war; the female characters are in the quest for truth and their journey involves identifying, confronting, and fighting the oppressor.

LUE MING: What is it like to kill a child? [...]

Why did you have to shoot her twice? Three times? Just to make sure? 
BOXLER: Just to make sure, I did it four times. And shooting a child, if you must know, is rather exceptional. It's like shooting an angel. There's something religious about it. (131)

This exchange embodies the brutality and the most inhuman aspects of war contrasting with the denouncement of barbarity. Although Lue Ming loses her child, she does not resort to violence, instead she raises her voice to demand moral sense and respect. This act of bravery contrasts with Lue Ming's playful attitude in previous apparitions; there is a change of tone that produces a shocking experience for the spectator, who aligns with the character.

On the contrary, the spectator is able to easily distance her/himself from the character of Boxler. One of the most aggressive scenes depicting Boxler's nature consists in his attempt to provoke an explosion of fury between the soldiers. Boxler repeatedly insults Craver and encourages him to fight against Remzi and, as a consequence, Craver, possessed by rage and frustration starts to choke Remzi. During the scene Boxler taunts the soldier and expresses his satisfaction with the aggressiveness by stimulating Craver:

BOXLER: Sodomite. Fairy. (Beat) Feel it? Feel it inside you, Mr. Perry? Now grab hold of it.

(Boxler finally pulls Craver off of Remzi)

Catch it. Hold it like a bullet between your teeth. And when the right moment comes, when you've spotted your enemy, let it rip, my son. (101)

The performance of this scene encapsulates different extreme emotions such as rage, anger, pain, fear, or hate. When watching the play the spectator surely has a short emotional episode, since she/he is immersed in all this action as well as the performers/characters. Physical appraisal is part of the spectators' emotional episodes, coordinative structures of the muscles are not restrained to facial muscles, for example squinting; the body also feels the tension, in the back or in the limbs that become stiff. Furthermore, some other experiences such as tickling in the stomach as a consequence of nervousness can also take place. Hence, the spectator's body is also experiencing the performance and functions as part of the performance, that is, the engaged spectator is heavily invested in the action of the play. 
Although Wallace has stated that she is interested in contradictions and questions, which is evident in the construction of most of her characters, Boxler is presented as responsible for war crimes and there is no place for ambiguity. What I find interesting is that perhaps the simplicity of this character's nature makes him more accessible to a wider public. Therefore, in scenes such as the one commented above, the experience that Wallace provides by introducing a character such as Boxler is closer to a more conventional theatrical experience and can be one of the possible aspects that make In the Heart of America more popular than the rest of her plays. The quotation mentioned above justifies the antipathy the spectator experiences towards this character; analyzing the spectator's emotional episode we might find antipathy, disgust, anger, and sadness for instance, all these feelings being part of a single emotional episode. Furthermore, an emotional episode is part of a relationship between the spectator and the performance where the spectator puts in motion her/his practical knowledge in relation to this ecosystem or, as I would rather say, 'micro ecosystem' since the theater can be considered a smaller unit.

In the same way that Lue Ming confronts Boxler, Fairouz is determined to cast some light on her brother's disappearance. Craver is reluctant to share anything with Fairouz at first. However, after several scenes and having conversations about personal anecdotes concerning their relationship with Remzi, Craver and Fairouz bond together and he agrees to explain to her the details of his absence:

CRAVER: They caught us together, out behind the barracks. They were lower ranks. Just kids. Like me. [...] Handed us over to an upper rank. There was a British officer and an Iraqi prisoner in there too, and they were laughing and saying: "Sandnigger. Indian. Gook." (Beat) Remzi. Well He went wild. He jumped one of those officers. I was standing there. I couldn't move. I couldn't...Then someone hit me over the head, and I went out. (Beat) [...] They were all over him [Remzi] and having a good time at it. Like kids in the snow. (Beat) Do you want to know how you died, Remzi?

REMZI: Friendly fire. (135)

This key moment of Remzi's story is not enacted on stage, although Remzi is not completely in absentia of his death, he is not the subject of scrutiny in his more vulnerable moment. Wallace decides to avoid the grotesque, which would certainly produce an impact on the 
spectator and send a clear anti-war message, she rather opts for an emotional testimony in accordance with her experimental style.

As McConachie asserts, empathy is not a feeling but it can lead to feelings. The dialogue above is appealing to imaginary transposition and invites the spectator to experience sympathy towards the characters. The audience understands how the young soldiers have been lured into the military life and once in the battlefield, they question the purpose of their mission. Memory also plays an important part in the spectator's emotional episodes; witnessing the fictional-but at the same time hypothetical bordering-reality of these two young soldiers' situation in the Gulf War, brings back the spectator's experiences and feelings towards the conflict. These feelings put the economic interests of the governments involved in war into the spectator's mind.

I find that Colombetti's theory on emotional episodes is appropriate to understanding the spectatorial experience of In the Heart of America and its consequent success because taking into account determinable factors such as embodiment and emotions helps to understand and study Wallace's plays, where the complexity of the spectatorial experience has to be acknowledged. This theory makes room for different nuances and does not oversimplify the nature of a spectator's emotions. The example of an emotional episode such as the one that goes with the dialogue above, where the spectator experiences not only emotions but also an embodied experience-which can be part of the facial and muscular expression, such as frowning that Colombetti calls the coordinative structures and preferential linkages among muscles (58)-adds value to the analysis of theater beyond a textual form and locates it as a performance. Colombetti's dynamic system models in affective science also take into account, as seen before, the interpersonal relationships, which in this case are related to coupling; the spectator couples with the character/performer and thanks to her/his cognitive empathy experiences the performance in a similar way to the performer.

Consequently, facing the fact that Remzi was beaten to death by his own colleagues is a disturbing and powerful moment for the spectator, who, immersed in the action of the play, has to receive Wallace's message; with this play she condemns gay bashing in the US army-which had become a national issue in the 90s and years after it is still an appalling episode of American recent history. In the Heart of America served to stage Wallace's awareness of this social 
issue that was publicly debated after the real case of the murder of Allen R. Schindler in the USA Navy. This incident brought about the policy "Don't Ask, Don't Tell" (DADT) in 1994 as an unsuccessful attempt to avoid gay discrimination, harassing, and bashing in the defense forces during the Clinton administration. ${ }^{3}$ In the Heart of America is a play about feelings and emotions, which in a bigger picture are connected with love and hate. It has been seen as a political story; nevertheless, its hopeful tone-represented in the final scene where the two soldiers are in the past racing, perhaps towards a more tolerant and pacific society-and its central idea of witnessing love amidst war are elements that shock and interest the spectator. Wallace has been described as extremely optimistic by playwrights such as Tony Kushner. She defends herself stating: "I am an optimist, an angry optimist" (Gardner, Enemy). Nevertheless, most of her final scenes give the chance of redemption to a corrupt, violent, and close-minded society.

Wallace encapsulates in this play our human and inhuman nature-although the spectators might fight different battles from those the protagonists undergo-universal aspects such as family, identity, death, hate, love or sex serve as the vehicle to experience emotional episodes that suggest the possibility to regain human nature after the follies of combat. Although I personally consider that Naomi Wallace has more interesting and complex plays, I cannot deny the fact that In the Heart of America possesses many appealing aspects, which achieve a unique portrait of war that makes the spectators wonder about our own human nature.

\section{WORKS CITED}

ARTAUD, Antonin. Theatre and Its Double. Grove Press, 1958.

BAYLEY, Clare. "Make love, not war: A play about Vietnam . . . written by a woman? Clare Bayley meets the playwright Naomi Wallace: part campus intellectual, part Kentucky farm-girl, all fighting talk." Independent.co.uk. Wednesday 3 August 1994.

\footnotetext{
3 Due to its failure, the policy was repealed during Obama's administration, see http://www.whitehouse.gov/blog/2010/12/22/president-signs-repeal-dont-ask-donttell-out-many-we-are-one.
} 
www.independent.co.uk/arts-entertainment/theatre-make-love-not-war-aplay-about-vietnam-written-by-a-woman-clare-bayley-meets-theplaywright-1374018.html.

COLOMBETTI, Giovanna. The Feeling Body: Affective Science Meets the Enactive Mind. Massachusetts Institute of Technology, 2014.

CUMMINGS, Lindsay B. "Naomi Wallace and the Dramaturgy of Rehearsal." The Theatre of Naomi Wallace: Embodied Dialogues, edited by Scot T. Cummings and Erica Stevens Abbitt, Palgrave, 2013, pp. 71-88.

CUMMINGS, Scott T. "Love in a Wound." The Theatre of Naomi Wallace: Embodied Dialogues. Edited by Scot T. Cummings and Erica Stevens Abbitt, Palgrave, 2013, pp. 35-44.

DIAMOND, Elin. "Brechtian Theory/Feminist Theory: Towards Gestic Feminist Criticism." Unmaking Mimesis. Routledge, 1997, pp. 43-55.

GALLESE Vittorio, Keysers Christian, and Rizzolatti Giacomo. "A Unifying View of the Basis of Social Cognition." Trends in Cognitive Sciences 8.9, September 2004, pp. 396-403.

GARDNER, Lyn. "Enemy Within.” The Guardian Tuesday 6 February 2007. www.guardian.co.uk/culture/2007/feb/06/lyngardner.features 11 . Accessed 15 November 2016.

GREENE, Alexis. "Naomi Wallace." Women Who Write Plays: Interviews with American Dramatists. Hanover, Smith and Kraus, 2001, pp 449-71.

HUFF, Helen. "A Land of Despair and Change: Landscapes of Wealth and Poverty in Selected Plays of Naomi Wallace." Revista de Estudios Norteamericanos 15, 2011, pp. 51-68.

ISTEL, John. "In the Heart of America: Forging Links." American Theatre 12.3, Mar 1995, p. 25.

MACDONALD, Claire. "Intimate Stories: Naomi Wallace in Conversation with Claire MacDonald." PAJ: A Journal of Performance and Art, 84, 28.3, September 2006, pp. 93-102.

MARGULIES, Donald and Wallace Naomi. "When Bad Things Happen: A Conversation between Donald Margulies and Naomi Wallace." American Theatre, 20.6, Jul/Aug 2003, pp.36. 
MCCONACHIE, Bruce. Evolution, Cognition, and Performance. Cambridge University Press, 2015.

OSENLUND, Kathryn. "A Curtain Up Review: In the Heart of America. Elyse Sommer." CurtainUp.com. The Internet Theater Magazine of Reviews, Features, Annotated Listings. 2004.

OZIEBLO, Barbara. "From Shirtwaist to Overalls: Cognition and the Embodiment of Abuse in Two Plays by Naomi Wallace." The Backyard of the U.S. Mansion, edited by José Antonio Gurpegui and Isabel Durán, Madrid: Instituto Franklin de Estudios Norteamericanos, 2012, pp. 115-129.

—. "'Pornography of Violence:' Strategies of Representation in Plays by Naomi Wallace, Stefanie Zadravec, and Lynn Nottage." Journal of American Drama and Theatre 23.1, Winter 2011, pp. 67-79.

WALLACE, Naomi. And I And Silence. Faber \&Faber 2011.

-. "Author's Introduction" to In the Heart of America. Staging Gay Lives. An Anthology of Contemporary Gay Theater, edited by John M. Clum. Westview Press, 1996, pp. 426-27.

-. In the Heart of America. In the Heart of America and Other Plays. Theatre Communications Group, 2001.

—. Night is a Room. Theatre Communications Group, 2016.

-. One Flea Spare. In the Heart of America and Other Plays. Theatre Communications Group, 2001.

—. The Liquid Plain. Theatre Communications Group, 2016.

- The Retreating World. The Fever Chart: Three Visions of the Middle East and One Short Sleepe. Theatre Communications Group, 2009.

- The War Boys. In the Heart of America and Other Plays. Theatre Communications Group, 2001. 